\section{Evidence for a territorial marking factor of mouse emotionality*}

\author{
OWEN EGAN†, J. R. ROYCE, and WAYNE POLEY \\ University of Alberta, Edmonton, Alta., Canada
}

The interpretation of an invariant factor of mouse emotionality as "territorial marking" was tested. Ninety mice from two emotionally divergent strains, $\mathrm{SJL} / \mathrm{J}$ and SWR/J, were obtained from the Jackson Laboratory. At 33 days of age, they were placed in separate cages and at 60 days of age they were run through a battery of tests consisting of 19 measures of emotionality. Scores were factor analyzed by alpha factoring, followed by varimax and then promax rotations. Factor scores were computed for all Ss on territorial marking and correlated with scores on nine tests of dominance and aggressiveness. The interpretation of Factor 1, territorial marking, was borne out by the correlations with social measures.

A 10-year program of research at the University of Alberta has uncovered invariant factors of emotionality (Royce, Poley, \& Yeudall, 1971a, b; Poley \& Royce, 1971), one of which loads mainly on urination measures and has been interpreted as territorial marking. We are hypothesizing that it is the same factor reported by McClearn \& Meredith $(1964)^{1}$, which also loaded on urination measures, with males scoring higher than females. From a zoologist's point of view, this interpretation is a mixture of anecdote, analogy, and guesswork. Though it has been shown that wild mice establish and maintain territories (Crowcroft, 1955), there is no evidence that they mark it in any way. Nevertheless, there is a strong resemblance between behavior patterns in rodents and territorial marking as it occurs in other species. In a paper on the laboratory rat, Grant (1963) says that in social encounters crawling over obstacles and sprinkling urine on them is evocative of olfactory territory marking as described by Hediger (1950), and the points marked in this way often seem to act as bases for the retreating animal. Rubbing against objects may have a similar significance. The golden hamster has scent glands in its flank, and the sebaceous glands in the rat may have a similar function (Grant \& Mackintosh, 1963).

Mykytowycz (1968) has shown that rabbits have glands under the chin and

* This research is reported from a thesis submitted by the first author in partial fulfillment of the MSc degree at the University of Alberta. Research was supported by National Research Council of Canada Grant APA-105, held by Joseph R. Royce.

+Requests for reprints should be sent to Owen Egan, Department of Psychology, University of Alberta, Edmonton, Alta., Canada. in the anus which are used for territorial marking. Secretions from the chin gland are directly applied to annexed "property" and territory; the anal gland provides an olfactory component in the fecal boli which then functions as markers when excreted. Field observation confirmed that these operations, and also urination, create an effective territorial boundary that is detected and avoided by "outsiders." In addition, the cellular structure of these glands was found (in section) to be more highly developed in dominant animals and the glands themselves always larger in males than in females.

It has yet to be demonstrated that inbred laboratory mice show territorial behavior in the strict sense of establishing a home range. The present study was not concerned with providing this type of demonstration. Instead, it assumed, following Grant (1963), that dominance and aggression in confined neutral areas are good indications of territoriality in any sense and should, therefore, show some correlation with the urination factor if it is indeed territorial marking. The measures of dominance selected were social grooming (Grant, 1963), fighting (Warne, 1947), tail-rattling (Scott, 1947), and squeaking in social encounters.

\section{SUBJECTS}

Forty-five $\mathrm{SJL} / \mathrm{J}$ and $\mathrm{SWR} / \mathrm{J}$ mice were used. In order to provide information for a companion study on the effects of litter size on emotionality (Egan \& Royce, 1971), the animals consisted of three litters of three, three litters of five, and three litters of seven for each strain.

Ss were weaned at 21 days but were not placed in individual cages until 33 days. Testing began at 60 days. Four animals had died by then, leaving a total of $86 \mathrm{Ss}$.

\section{APPARATUS}

All apparatus was derived from previous studies (e.g., see Royce, Carran, \& Howarth, 1970; Royce, Poley, \& Yeudall, 1971a, b; Poley \& Royce, 1971). More complete details can be obtained in these reports. Five tests were selected from the complete battery as being adequate to replicate the factors previously found.

Open Field

This consists of a white circular field, $4 \mathrm{ft}$ in diam, divided into concentric circles, with intersecting lines radiating outward from the center of the field. Five measures are taken during a 2-min trial: latency to leave the start section, activity, penetration into the center of the field, defecation, and urination.

\section{Straightaway}

This is an elevated runway, $50 \mathrm{in}$. long and $1.5 \mathrm{in.}$ wide. Measures recorded in a 3-min trial are: latency to leave the start section, activity, defecation, and urination.

\section{Pole}

In this test, the $S$ is placed on a wire mesh platform on top of a metal pole 34 in. high. The animal is able to descend by a vertical wire-mesh ladder. Measures recorded are: latency to leave the top, latency to descend, defecation, and urination.

Cell and Hole-in-Wall

In the cell test the $S$ is placed in a small dark compartment ( $4 \times 4 \times 3$ in.) and is able to emerge through a small door into a bright compartment of the same size. The hole-in-wall tests involve emergence from the bright compartment into the dark compartment. Latency to emerge, defecation, and urination are recorded.

Upon completion of this battery, Ss were tested for dominance and aggression in social situations. Ss were placed two at a time in a metal cage (9.5 × $5 \times 4$ in.), similar to their home cages except for the Plexiglas cover through which observations were made. Each $\mathbf{S}$ was given four to six trials, at least two with another male and two with another female, always drawn from littermates. Squeaking, grooming, and tail-rattling were observed and the following mean scores recorded: ${ }^{2}$ (1) times groomed by male partner, (2) times groomed by female partner, (3) number of squeaks in encounter with male, (4) number of squeaks in encounter with female, (5) number of groomings of male partner, (6) number of groomings of female partner, (7) number of squeaks by male partner, (8) number of squeaks by female partner, and (9) tail-rattling (presence or absence). TESTING

Measures of emotionality were taken with white noise, with the speaker approximately $30 \mathrm{in}$. from the apparatus and intensity set at $85 \mathrm{~dB}$. Open field, straightaway, and pole 
were administered on Day 60 and again on Day 61. Open field was run at 9:00 a.m., straightaway at noon, and pole at 6:00 p.m. Cell was administered on Day 62 at 9:00 a.m. and 9:00 p.m. and hole at the same times on Day 63. All scores were averaged over the two trials. Social tests were administered on Days 64-72 between 9:00 a.m. and 9:00 p.m. No animal was tested more than twice on 1 day. White noise was not used.

\section{ANAL YSIS}

Scores on the 19 measures of emotionality were analyzed by alpha factoring (Kaiser \& Caffrey, 1965). Factoring was terminated when eigenvalues became less than one. The factors were rotated to oblique simple structure by varimax (Harman, 1967, pp. 304-313), followed by promax (Hendrickson \& White, 1964) rotations. Promax plots were obtained and found to yield satisfactory simple structure. Thus, no further graphic rotations were required. Factor scores on territorial marking were obtained by the formula $F=A^{\prime} R^{-1} Z$, where $A$ is the $\mathrm{n} \times \mathrm{m}$ factor structure matrix, $\mathrm{Z}$ is the $\mathrm{n} \times \mathrm{n}$ matrix of standard scores, and $\mathbf{R}$ is the $\mathbf{n} \times \mathbf{n}$ correlation matrix. A mean of 50 and a standard deviation of 10 were used. Factor scores were then correlated with scores on the nine social tests.

\section{RESULTS}

Of the six factors obtained, four were readily identified with factors previously interpreted as territorial marking, autonomic balance, acrophobia, and motor discharge. Although this research is focused on only one factor, territorial marking, it should be noted in passing that the present replication adds credence to the invariance of all the factors mentioned (see Poley \& Royce, 1971, for a more complete summary of invariant emotionality factors). The major loadings on territorial marking are presented in Table 1. The correlation of factor scores on this factor with the nine measures of social dominance are presented in Table 2 . Although the absolute magnitudes are low, scores on territorial marking are significantly correlated with squeaking
Table 1

Major Loadings on Factor 1

\begin{tabular}{lc}
\multicolumn{1}{c}{ Variables } & Loadings \\
\hline Open Field Urination & .52 \\
Straightaway Urination & .64 \\
Pole Urination & .32 \\
Cell Urination & .64 \\
Hole Urination & .78 \\
\hline
\end{tabular}

in encounters with males $(\mathrm{r}=-.31$, $\mathrm{df}$ $=84, p<.01$ ), with grooming of male partners $(\mathrm{r}=.36, \mathrm{df}=84, \mathrm{p}<.01)$, and with tail-rattling $(\mathrm{r}=.25, \mathrm{df}=84$, $\mathrm{p}<.05)$. Correlations with the other variables wery not significant.

\section{DISCUSSION}

A relationship between the factor interpreted as territorial marking and social dominance is established by the results, as shown in Table 2. E observation suggests that squeaking in social encounters is an indication of submissiveness in mice. The fact that it is negatively correlated with territorial marking indicates, therefore, that low scores on the factor are associated with social submissiveness and high scores with dominance. The same conclusion can be drawn from the positive correlations obtained between scores on the factor and grooming of male partners and tail-rattling. Grant (1963) and Grant \& Mackintosh (1963) claim that in caged animals, where expulsion and flight are impossible, aggressive grooming substitutes for the establishment and defense of territory. Finally, tail-rattling is a reliable indicator of aggression in mice, and it is almost always followed by fighting (Scott, 1947; Southwick \& Clark, 1968). In the present study it was observed only in males.

Although the absolute value of the significant correlations are low, they are, in fact, comparable to the bulk of correlations reported in the comparative psychology literature. The reasons for this are complex, and they have been discussed at length elsewhere (Royce, 1966). They include such matters as low test-retest reliabilities (not due to experimental error) and the probability that underlying relationships are

Table 2

Correlations of Factor Scores on Territorial Marking with Social Behavior

\begin{tabular}{clc}
\hline & \multicolumn{1}{c}{ Social Behavior } & r \\
\hline $\mathbf{1}$ & Times groomed by male partner & .00 \\
$\mathbf{2}$ & Times groomed by female partner & -.12 \\
4 & Squeaks in encounter with male & $-31 \dagger$ \\
$\mathbf{5}$ & Squeaks in encounter with female & .13 \\
6 & Grooming of male partner & $.36 \dagger$ \\
7 & Grooming of female partner & .04 \\
8 & Squeaks by male partner & .00 \\
9 & Tail-rattling & .13
\end{tabular}

$* p<.05, \quad+p<.01$ curvilinear, with the result that linear correlation procedure provides lower estimates than the true relationships. What should be kept in mind is the fact that multivariate methods of analysis, such as factor analysis and correlational analysis, have been able to identify meaningful and replicable "behavior patterns" in spite of low surface intercorrelations. Furthermore, bivariate experimental extensions of a factor, such as we have summarized in this report, constitute an important extrafactorial validation of a theoretical construct (Royce, 1963). It can be anticipated that such complementary research will eventually improve the reliability of particular measures and, more importantly, reveal the underlying multiplicity of curvilinear relationships (Royce, 1950).

Six other possible measures of dominance and/or aggression showed little or no correlation with territorial marking. This is easily explained in the case of the grooming measures. In the course of testing, it became apparent that the definition of grooming as "mouthing or licking the fur of another animal" covered instances of grooming which were clearly not associated with dominance. In fact, Southwick \& Clark (1968) have even found a slight negative correlation between grooming and aggression for some strains of mice. This fact, however, was brought to our attention too late to refine the definition of grooming so as to exclude nonaggressive varieties. Similarly, encounters involving a female produced almost no aggression, and it was not surprising that squeaking in such circumstances showed little relation to territorial marking. It is well known that social dominance in rodents, as in almost all mammals, is exclusively the concern of the male (Wynne-Edwards, 1962, Chap. 8). There is only one nonsignificant correlation that is unexpected, i.e., that with squeaking by a male opponent. On the whole, therefore, the interpretation of the factor in question as territorial marking is supported by the study, and further confirmation from physiology and field observation can be expected in the future.

\section{REFERENCES}

BURT, C. L. The factorial study of temperament traits. British Journal of Psychology (Statistical Section), 1948, 1, 178-203.

CATTELL, R. B., BALCAR, K. R., HORN, J. L., \& NESSELROADE, J. R. Factor matching procedures: An improvement of the $s$ index, with tables. Educational \& Psychological Measurement, 1969, 29. 781-792

CROWCROFT, P. Territoriality in wild housemice. Journal of Mammalogy, 1955. $36,299-301$.

EGAN, O., \& ROYCE, J. R. Litter-size and 
emotionality in two strains of mice. Unpublished manuscript. University of Alberta, 1971.

GRANT, E. C. An analysis of the socia behaviour of the male laboratory rat. Behaviour, 1963, 21, 260-281.

GRANT, E. C. \& MACKINTOSH, J. H. A description of the social postures of some laboratory rodents. Behaviour, 1963, 21 . 246-259.

HARMAN, H. H. Modern factor analysis. Chicago: University of Chicago Press, 1967.

HEDIGER, H. Wild animals in captivity. London: Butterworths, 1950.

HENDRICKSON, A. E., \& WHITE, P. 0 Promax: A quick method for rotation to oblique simple structure. British Journal for Statistical Psychology, 1964, 17 65-70.

KAISER, H. F., \& CAFFREY, J. Alpha factor analysis. Psy chometrika, 1965, 30, 1-14.

MCCLEARN, G. E., \& MEREDITH, W Dimensional analysis of activity and elimination in genetically heterogeneous mice. Animal Behaviour, 1964, 12, 1-10.

MYKYTOWYCZ, $R$. Territorial marking in rabbits. In $\mathrm{N}$. K. Wessells (Ed.) Vertebrate adaptations: Readings from the Scientific American. San Francisco: Freeman, 1968.

POLEY, W., \& ROYCE, J. R. Behavior-genetic analysis of mouse emotionality: II. Stability of factors across mating plans. Unpublished manuscript, University of Alberta, 1971

ROYCE, J. R. The factorial analysis of animal behavior. Psychological Bulletin, $1950,47,235-259$

ROYCE, J R Factors as theoretical constructs. American Psychologist, 1963. $18,522-528$.

ROYCE, J. R. Concepts generated in comparative and physiological psychological observations. In $R$. $B$. Cattell (Ed.), Handbook of multivariate experimental psychology. Chicago: Rand-M cNally, 1966 .

ROYCE, J. R., CARRAN, A., \& HOWARTH, E. Factor analysis of emotionality in 10 inbred strains of mice. Multivariate Behavioral Research, 1970, $5,19-48$.

ROYCE, J, R., POLEY, W. \& YEUDALL, L. T. Behavior-genetic analysis of mouse emotionality: I. The factor analysis. Unpublished manuscript, University of Alberta, 1971a

ROYCE, J. R., POLEY, W., \& YEUDALL, L. T. Behavior-genetic analysis of mouse emotionality: III. The diallel analysis. Unpublished manuscript, University of Alberta, $1971 \mathrm{~b}$

SCOTT, J. P. Emotional behavior in fighting mice caused by conflict between weak stimulatory and weak inhibitory training. Journal of Comparative \& Physiological Psychology, 1947, 40, 275-282.

SOUTHWICK, C. H., \& CLARK, L. H. Interstrain differences in aggressive behavior and exploratory activity in inbred mice. Communications in Behavioral Biology, 1968, Part A, 1 , 49-59.

TRYON, R. C. Studies in individual differences in maze ability: I. The measurement of the reliability of individual differences. Journal of Comparative \& Physiological Psychology, $1930,11,145-170$.

TRYON, R. C.. TRYON, C. M., \& KUZNETS, G. Studies in individual differences in maze ability: IX. Ratings of hiding, avoidance, escape, and vocalization responses. Journal of Comparative \& Physiological Psychology, $1941,32,407-435$.

WARNE, M. C. A time analysis of certain aspects of the behavior of small groups of caged animals. Journal of Comparative \& Physiological Psychology, 1947, 40, 371-387.

WYNNE-EDWARDS, V. C. Animal dispersion in relation to social behavior. Edinburgh, Scotland: Oliver \& Boyd, 1962.

\section{NOTES}

1. It should be possible to eventually verify this by quantitative indices of invariance (see Royce, 1966). For example, invariance coefficients have been developed by Burt (1948) and Cattell et al (1969).

2 . The authors are aware of the fact that these data do not provide information concerning the reliability of each measure. Except for the early contributions of Tryon $(1930,1941)$, there has been very little application of psychometric theory to comparative psychology. Note, however, that it is reasonable to expect some degree of reliability, since each score is actually an average of repeated measures. 